Jurnal Intelektualita: Keislaman, Sosial, dan Sains

Vol. 10 No. 2 (2021)

DOI: https://doi.org/10.19109/intelektualita.v10i2.8907

Copyright (C) 2021 Muhammad Ihsan

\title{
Kedudukan Kejaksaan Republik Indonesia dalam Proses Penuntutan Peradilan Militer di Indonesia
}

\author{
Muhammad Ihsan ${ }^{1 *}$ \\ ${ }^{1}$ UIN Raden Fatah Palembang, Indonesia
}

\begin{abstract}
Abstrak: Penelitian ini bertujuan untuk menganalisis kedudukan jaksa dan penerapan asas equality before the law dalam sistem Peradilan Militer di Indonesia. Metode penelitian yang digunakan adalah penelitian hukum normative. Setelah data-data terkumpul, kemudian dianalisis dengan menggunakan metode deskriptif analitis dan diinterpretasikan dengan pendekatan yang telah ditentukan. Penelitian ini menyimpulkan bahwa dengan berlakunya Undang-Undang Kejaksaan Tahun 2004, kewenangan Jaksa Agung sebagai Penuntut Umum Tertinggi tetap melekat sebagaimana diatur dalam Pasal 18 ayat (1) Undang-Undang ini. Namun dalam praktiknya khusus dalam peradilan militer, kewenangan penuntutan oleh Jaksa Agung hanya terbatas pada aspek pengawasan, meskipun secara organisatoris Oditur Jenderal melalui Panglima bertanggung jawab kepada Jaksa Agung dalam melaksanakan tugas di bidang teknis penuntutan.
\end{abstract}

Kata Kunci: Kejaksaan Republik Indonesia, Peradilan Militer, Equality Before The Law

\begin{abstract}
This study aims to analyze the position of the prosecutor and the application of the principle of equality before the law in the military justice system in Indonesia. The research method used is normative legal research. After the data has been collected, it is then analyzed using descriptive analytical methods and interpreted with a predetermined approach. This research concludes that with the enactment of the Prosecutor's Law of 2004, the authority of the Attorney General as the Highest Public Prosecutor remains attached as regulated in Article 18 paragraph (1) of this Law. However, in practice specifically in military courts, the prosecutor general's authority to prosecute is only limited to the aspect of supervision, although organizationally the Prosecutor General through the Panglima is responsible to the Attorney General in carrying out his duties in the technical field of prosecution.
\end{abstract}

Keywords: Prosecutor's Office of the Republic of Indonesia, Military Courts, Equality Before The Law

\section{Pendahuluan}

Indonesia merupakan sebuah negara yang berlandaskan negara kesatuan, meskipun pada awalnya Indonesia masih negara perserikatan. Konfrensi Meja Bundar (KMB) menjadi awal yang mana Indonesia menyatakan bahwa Indonesia mulai membentuk konstitusi negara Republik
Indonesia Serikat. Hasil pernyataan KBM yang menyatakan bahwa Belanda menyerahkan kedaulatan negara Indonesia pada negara Republik Indonesia Serikat tanpa syarat, dan tidak akan mencabut konstitusi Republik Indonesia Serikat (RIS) tersebut.

Pembentukan Republik Indonesia Serikat (Sari, 2019) ternyata mengalami berbagai gejolak

\footnotetext{
* Corresponding Author: Muhammad Ihsan (muhammadihsan585@gmail.com). UIN Raden Fatah Palembang, Indonesia
} 
yang sulit untuk ditangani oleh para pendiri bangsa. Mulai dari permasalahan perang yang tak kunjung selesai hingga perkembangan ekonomi di Indonesia semakin memburuk dan semakin banyak masyarakat di Indonesia mengalami kerusakan mental karena tidak kuat untuk mengalami keterpurukan masalah ekonomi. Adanya berbagai masalah yang menerjang negara Indonesia membuat masyarakat mendesak pemerintah untuk membentuk kembali Negara Kesatuan Republik Indonesia (NKRI) dengan salah satu catatan yang menyatakan bahwa masyarakat menginginkan untuk menuntut wilayah peradilan, dengan mengembalikan sistem pemerintahan Indonesia kembali ke dalam Republik Indonesia dengan aturan pada Undang-Undang Dasar (UUD) 1945.

Sejatinya bahwa Pengadilan Negeri, Pengadilan Tinggi, dan Mahkamah Agung merupakan peradilan yang diwariskan oleh Belanda (Landgerecht dan Appelraad) kepada Indonesia, tidak terkecuali Peradilan Militer. Sejak jaman Belanda menduduki Indonesia, Belanda sudah menerapkan sistem peradilan miliknya di Indonesia. Peradilan Militer Belanda di Indonesia dikenal dengan "Krijgsraad" dan "Hoog Militair Gerechtshof". Peradilan ini ruang lingkupnya meliputi perbuatan pidana militer dan anggotaanggotanya terdiri dari Angkatan Darat Belanda di Indonesia (Hindia Belanda) yaitu KNIL dan anggota Angkatan Laut Belanda. Anggota Angkatan Darat Hindia Belanda (KNIL) di periksa dan di adili oleh "Krijgsraad" untuk tingkat pertama dan "Hoog Militair Gerechtshof" untuk tingkat banding (Utama, 2019).

Pada tahun 1997, dibentuk undang-undang yang dianggap dapat mengakomodir permasalahan tentang peradilan militer di Indonesia. Pada Pasal 40 Undang-Undang Nomor 31 Tahun 1997 tentang Peradilan Militer meyatakan bahwa Peradilan Militer merupakan pengadilan yang memiliki tugas pokok dan fungsi yaitu memeriksa dan memutus perkara pada tingkat pertama terhadap perkara pidana yang dilakukan oleh Prajurit TNI aktif, dimana terdakwanya berpangkat Kapten ke bawah. Pada undang-undang tersebut tidak hanya mengatur mengenai sistem peradilan militer saja, melainkan juga mengatur mengenai oditurat dan hukum acara militer. Oditurat adalah badan di lingkungan Angkatan Bersenjata Republik Indonesia yang melakukan kekuasaan pemerintahan negara di bidang penuntutan dan penyidikan berdasarkan pelimpahan dari Panglima Angkatan Bersenjata Republik Indonesia.

Oditurat memiliki tugas dan wewenang yang hampir sama dengan jaksa. Kejaksaan atau bisa disebut Kejaksaan Republik Indonesia adalah lembaga pemerintahan yang melaksanakan kekuasaan negara secara merdeka terutama pelaksanaan tugas dan kewenangan di bidang penuntutan dan melaksanakan tugas dan kewenangan di bidang penyidikan dan penuntutan perkara tindak pidana korupsi dan Pelanggaran HAM berat serta kewenangan lain berdasarkan undang-undang. Jaksa sebagai wakil negara dalam melakukan penyelidikan dan penuntutan juga memiliki batasan yang jelas. Selain terdapat suatu perkara tindak pidana ataupun permasalahan yang menyangkut aspek hukum publik atau melibatkan negara sebagai pihak, maka jaksa tidak memiliki kewenangan untuk melakukan penyelidikan dan penuntutan.

Pada pasal 69 Undang-Undang No. 31 Tahun 1997 tentang Peradilan Militer menyatakan bahwa terdapat tiga penyidik, yaitu atasan yang berhak menghukum, polisi militer dan oditur. Disini jelas bahwa oditur memiliki peran yang vital sebagai pengganti Jaksa yang berperan dalam melakukan penyelidikan. Tetapi terdapat permasalahan yang cukup penting yang mana oditur dalam pengadilan militer tidak mempunyai wewenang untuk 
menyerahkan secara langsung suatu perkara pidana ke pengadilan militer tanpa persetujuan atasan yang berhak menghukum, meskipun pada dasarnya penyerahan perkara pidana ke pengadilan militer melalui oditur militer (Pratma, 2019).

Ini menjadi sebuah pertanyaan bahwa pada Undang-Undang Nomor 31 Tahun 1997 tentang Peradilan Militer sudah jelas menyatakan bahwa fungsi dan wewenang dalam melakukan penyelidikan serta penuntutan yang pada umumnya dilakukan oleh jaksa sudah digantikan oleh oditur yang memiliki tugas serupa. Ini menandakan bahwa pengadilan militer berusaha untuk mandiri terlepas dari sistem penuntutan pidana pada umumnya. Peradilan militer dibentuk karena sebuah alasan tertentu. Militer sebagai orang terdidik, dilatih dan dipersiapkan untuk bertempur, bagi mereka diadakan norma-norma yang khusus. Mereka harus tunduk tanpa reserve pada tata kelakuan yang telah ditentukan dan diawasi dengan ketat. Karena kekhususan dalam mengemban tugas ini, mengakibatkan terjadinya pemisahan peradilan anggota tentara dengan masyarakat umum. Penegakan disiplin yang sangat ketat dan harus dipertanggung jawabkan di lembaga khusus jika melanggar. Mereka diadili dengan aturan yang khusus berlaku bagi mereka dengan tidak mengesampingkan kenyataan yang hidup ditengah masyarakat (Nurdin, 2019).

Di lain sisi, Dalam melakukan penuntutan di pengadilan, terdapat peran Jaksa yang krusial. Kejaksaan memiliki wewenang untuk melakukan penuntutan, melaksanakan penetapan hakim dan putusan pengadilan, melakukan pengawasan terhadap pelaksanaan putusan pidana dan sebagainya, sesuai dengan tugas dan wewenang yang terdapat pada Undang-Undang No. 16 Tahun 2004 tentang Kejaksaan. Peran kejaksaan disini tidak lain adalah sebagai "wakil negara" dalam melakukan penuntutan, sehingga kejaksaan memiliki peran di setiap lembaga peradilan, tidak terkecuali peradilan militer. Meskipun dalam peradilan militer terdapat oditur sebagai penyidik dan penuntut, peran kejaksaan tidak serta merta hilang. Jaksa masih memiliki peran dalam segi pengawasan, karena oditur bertanggung jawab kepada Jaksa Agung dalam melaksanakan tugas di bidang teknis penuntutan dan juga dalam hal koordinasi dan putusan penentuan pengadilan yang berwenang mengadili perkara.

Indonesia sebagai negara hukum yang berdasarkan Pancasila dan Undang-Undang Dasar Tahun 1945 (selanjutnya disebut UUD 1945), bertujuan untuk mewujudkan tata kehidupan masyarakat, bangsa, dan negara yang tertib aman dan sejahtera serta adil dan makmur, salah satu faktor yang sangat penting dalam mewujudkan tujuan nasional tersebut adalah aspek pertahanan negara. Pembukaan UUD 1945 menyatakan bahwa tujuan dibentuknya negara Indonesia adalah melindungi segenap bangsa Indonesia dan seluruh tumpah darah Indonesia, memajukan kesejahteraan umum, mencerdaskan kehidupan bangsa dan ikut melaksanakan ketertiban dunia yang berdasarkan kemerdekaan, perdamaian abadi dan keadilan sosial. Pengwujudan segala tata kehidupan masyarakat yang tertib, aman, dan sejahtera, adil dan makmur tersebut tidak terlepas dari upaya pertahanan negara yang maksimal.

Tentara Nasional Indonesia atau anggota militer merupakan bagian warga negara Indonesia yang sama kedudukannya dengan anggota masyarakat biasa yang ada kemungkinan melakukan suatu pelangaran hukum. Apabila dipandang dari perspektif sistem peradilan pidana di Indonesia, maka anggota militer mempunyai kedudukan yang sama dengan anggota masyarakat biasa (masyarakat sipil). Terhadap anggota militer 
yang melakukan suatu pelangaran hukum disamping diberlakukan peraturan-peraturan yang berlaku secara umum juga diberlakukan peraturanperaturan yang bersifat khusus. S.R. Sianturi di dalam bukunya menyebutkan bahwa hukum militer dapat mencakup Hukum Disiplin Militer; Hukum Pidana Militer; Hukum Pidana; Hukum Acara Pidana Militer; Hukum Acara Pidana; Hukum Kepenjaraan Militer; Hukum Pemerintahan Militer atau Hukum Tata Negara (Darurat) Militer; Hukum Administrasi Militer; Hukum Internasional (Hukum Perang/ Hukum Sengketa Bersenjata); dan Hukum Perdata Militer (Sianturi, 2011).

Secara umum dalam setiap negara yang menganut paham negara hukum dapat dilihat bekerjanya tiga prinsip dasar, yaitu supremasi hukum (supremacy of law), kesetaraan di hadapan hukum (equality before the law), dan penegakan hukum yang tidak bertentangan dengan hukum (due process of law). Dalam penjabaran selanjutnya pada setiap negara hukum akan terlihat ciri-cirinya yaitu 1) jaminan perlindungan Hak Asasi Manusia; 2) kekuasaan kehakiman atau peradilan yang merdeka; dan 3) legalitas dalam arti hukum yaitu bahwa baik pemerintah/ negara maupun warga negara dalam bertindak harus berdasarkan atas dan melalui hukum.

Peradilan Militer merupakan pelaksana kekuasaan kehakiman di lingkungan TNI dalam menegakkan hukum dan keadilan dengan memperhatikan kepentingan penyelenggaraan pertahanan negara. Disahkannya UUD 1945 telah membawa perubahan yang besar dalam kehidupan pelaksanaan ketatanegaraan khususnya dalam pelaksanaan kekuasaan kehakiman (Siahaan, 2017).

Peraturan khusus inilah yang dalam lingkup kajian militer yang mengatur tentang anggota militer. Demikian pula dengan hukum pidana telah diadakan dan diberlakukan peraturan-peraturan khusus bagi anggota militer yang dikenal dengan hukum pidana militer (Sjarif, 1996). Hukum pidana militer yang berlaku sekarang ini telah diatur dan dimuat dalam Kitab Undang-undang Hukum Pidana Militer (KUHPM). KUHPM ini sebenarnya berasal dari wetboek van Militaire Strafrecht voor Nederlandsch Indie, Staadblad 1934 Nomor 167 yang melalui Undang-undang Nomor 39 Tahun 1947 disebut dengan Kitab Undang-undang hukum Pidana Tentara (KUHPT) dan sekarang lebih dikenal dengan Kitab Undang-Undang Hukum Pidana Militer (KUHPM).

\section{Metode Penelitian}

Metode penelitian yang digunakan adalah penelitian hukum normatif dengan pendekatan konseptual. Sumber data yang digunakan di antaranya Undang-Undang Dasar Negara Republik Indonesia Tahun 1945, Undang-Undang Nomor 29 tahun 1954 tentang pertahanan negara, Undang Undang Nomor 34 Tahun 2004 tentang Tentara Nasional Indonesia Undang-Undang Negara Republik Indonesia Nomor 7 Tahun 1946 tentang Peraturan Mengadakan Peradilan Tentara, UndangUndang Negara Republik Indonesia Nomor 8 Tahun 1946 tentang Hukum Acara Pidana Guna Peradilan Tentaradan Peraturan perundangundangan lainnya terkait dengan kedudukan kejaksaan dalam ketatanegaraan Republik Indonesia. Setelah data-data terkumpul, kemudian dianalisis dengan menggunakan metode deskriptif analitis dan diinterpretasikan dengan pendekatan yang telah ditentukan.

\section{Hasil dan Pembahasan}

Kejaksaan yang menjalankan fungsi penuntutan dalam Bahasa Inggris, disebut sebagai "Prosecution Service". Prosecution berasal dari Bahasa Latin, yaitu prosecutes yang terdiri dari 
imbuhan pro (sebelum) pada kata sequi (mengikuti) dalam arti "proses perkara dari awal hingga selesai". Prosequi berarti "menuntut". Dengan demikian, prosecutor (Jaksa) adalah "pejabat publik yang berwenang melakukan proses perkara dari awal hingga selesai melalui tahap dakwaan" (Hamzah dan Surachman, 2014).

Di era IR 1848, “djaksa” berada dibawah seorang magistraat, yaitu Residen. Penuntut umum untuk golongan Bumi Putera, bergabung ke dalam korsa (corps) Binnenlands Bestuur (BB) atau "pangreh praja" (sekarang PNS Kementrian Dalam Negeri). Dan di era HIR 1941, "djaksa" barulah berstatus sebagai magistrate. Akhirnya, dalam KUHAP 1981 ditemukan istilah "jaksa" dan istilah "penuntut umum", tapi dalam keseharian dikenal sebagai JPU (Jaksa penuntut umum) (Hamzah dan Surachman, 2014). Pasal 1 angka 7 KUHAP 1981 mendefinisikan penuntutan sebagai tindakan penuntut umum untuk melimpahkan perkara pidana ke pengadilan yang berwenang dengan permintaan supaya diperiksa dan diputus oleh hakim di sidang pengadilan". Pengertian penuntutan tersebut, dalam Bahasa Inggris disebut sebagai committal. Tindakan penyerahan perkara (committal) adalah sebagian dari penuntutan (prosecution). Dalam tradisi negara-negara bersistem common law dan anglo-american law, penuntutan bermula sejak pengumpulan alat bukti dan berakhir, hingga terdakwa dihadapkan kepada hakim. Yaitu, sejak polisi melakukan pengumpulan alat bukti, penuntutan berjalan, hingga perkara diakhiri oleh yang berhak mengakhiri perkara, yaitu penuntut umum atau hingga penyerahan perkara ke pengadilan. Singkatnya, hanya Jaksa, yang berwenang menyelesaikan perkara. Prosedur demikian berlaku misalnya di Singapura dan di Malaysia (Effendy, 2005).
Dari sudut kompetensi sistem kekuasaan kehakiman di Indonesia mengenal 5 macam jenis peradilan, yaitu peradilan umum, peradilan agama, peradilan tata usaha Negara, peradilan militer dan mahkamah konstitusi, masing-masing peradilan mempunyai obyek dan subyek yang berbeda dan kekhususan tersendiri.

Pada era reformasi yang menuntut transparansi, kebebasan, demokratisasi dan persamaan hak, berimbas kepada penyelenggaraan peradilan. Prinsip Equality Before The Law menghendaki tidak ada warga Negara yang mendapat prevelege apalagi dalam bidang peradilan. Oleh karena itu tuntutan bahwa militer yang melakukan tindak pidana umum diadili di peradilan umum terus bergaung dan puncaknya adalah dikeluarkannya TAP MPRI RI Nomor VI/2000 dan TAP MPR RI Nomor VIII/2000 Jo Undang-undang Nomor 34 Tahun 2004 tentang TNI yang menegaskan bahwa anggota militer yang melakukan kejahatan umum di bawa ke pengadilan sipil. Sedangkan Undang-undang Nomor 31 tahun 1997 tentang peradilan Militer mengatakan tindak pidana yang dilakukan anggota militer baik tindak pidana umum sebagaimana diatur dalam KUHP dan perundan-undangan pidana lainnya, juga tindak pidana militer sebagaimana terdapat dalam KUHPM semuanya diadili di peradilan militer.

Corak kehidupan militer merupakan suatu corak kehidupan khusus, terikat akan suatu disiplin yang diatur tersendiri dalam hukum disiplin militer, yang hanya dapat dimengerti oleh anggota militer, maka dirasakan perlunya fungsi peradilan militer itu diselenggarakan oleh anggota militer (Sugiri, 1976). Posisi peradilan militer dalam sistem peradilan negara yang dianut dan diberlakukan di Indonesia dalam bentuknya seperti sekarang ini dapat dijelaskan dalam berbagai perundangundangan. Disatu pihak Undang Undang Dasar 
1945 amandemen keempat menentukan bahwa kekuasaan kehakiman ialah kekuasaan yang merdeka terlepas dari pengaruh pemerintah, mengandung asas independent judiciary yang menjadi ideologi universal masa kini dan masa datang. Di lain pihak Pasal 30 UUD 1945 dijabarkan lebih lanjut oleh Pasal 43 Undang Undang Nomor 20 Tahun 1982 dinyatakan bahwa hukum militer dibina dan dikembangkan sesuai kepentingan pertahanan keamanan negara, dan angkatan bersenjata mempunyai peradilan sendiri serta komandan-komandan mempunyai wewenang penyerahan perkara. Kekuasaan lembaga peradilan yang independen dimaksudkan untuk tidak adanya campur tangan lembaga-lembaga di luar peradilan, terutama kekuasaan eksekutif dan yudikatif.

Aparat Negara yang diberi kewenangan untuk melakukan penyidikan terhadap seorang anggota militer sesuai pasal 69 ayat (2) Undangundang Nomor 31 Tahun 1997 adalah atasan yang berhak menghukum, polisi militer tertentu dan oditur yang diberi wewenang khusus oleh Undangundang nomor 31 Tahun 1997.

Atasan Yang Berhak Menghukum adalah atasan langsung tersangka yang memiliki kewenangan untuk menjatuhkan hukuman disiplin terhadap tersangka berdasarkan Undang-Undang Nomor 31 Tahun 1997 dan memiliki kewenangan untuk memerintahkan suatu penyidikan terhadap pelanggaran hukum pidana oleh seorang anggota mliter.

Institusi militer merupakan institusi unik karena peran dan posisinya yang khas dalam struktur kenegaraan. Sebagai tulang punggung pertahanan negara, institusi militer dituntut untuk dapat menjamin disiplin dan kesiapan prajuritnya dalam menghadapi segala bentuk ancaman terhadap keamanan dan keselamatan negara. Untuk itu, hampir semua institusi militer di seluruh negara memiliki mekanisme peradilan khusus yang dikenal sebagai peradilan militer. Di Indonesia, peradilan militer diatur dalam Undang-Undang Nomor 31 Tahun 1997 tentang Peradilan Militer. Terhadap setiap perbuatan yang merupakan pelanggaran hukum dengan kategori tindak pidana yang dilakukan oleh Prajurit TNI atau yang dipersamakan dengan Prajurit TNI, maka berdasarkan ketentuan Hukum Pidana Militer harus diproses melalui Pengadilan Militer.

Selain itu dalam Undang-Undang Peradilan Militer, diatur pula beberapa hal mengenai yurisdiksi peradilan militer, struktur organisasi dan fungsi peradilan militer, hukum acara peradilan militer dan acara koneksitas, serta hukum tata usaha militer. Namun dengan menguatnya wacana demokrasi dan hak asasi manusia, telah mendorong dilakukannya perubahan mendasar sistem peradilan militer, terutama dalam hal yurisdiksi peradilan militer itu sendiri melalui reformasi sektor keamanan yang pada intinya bertujuan untuk menciptakan good governance di sektor tersebut. Maka pada masa reformasi saat ini sistem peradilan militer Indonesia sudah mulai bergeser menuju sistem yang didominasi sipil seperti Filipina, Singapura dan Malaysia dengan menempatkan anggota angkatan bersenjata yang melakukan tindak pidana umum dalam peradilan sipil meskipun peraturan pelaksanaannya masih dalam argumentasi rumusan yang belum selesai.

Sesuai Pasal 9 Undang-Undang No. 31 Tahun 1997 tentang Peradilan Militer, dikaitkan dengan Pasal 1 dan 2 Kitab Undang-Undang Hukum Pidana Militer (KUHPM), maka Peradilan Militer mengadili tindak pidana didasarkan pada subyeknya, yaitu prajurit (militer) atau yang dipersamakan. Dengan kata lain, selama ia militer, dan melakukan tindak pidana apa saja, baik tindak pidana militer (murni), seperti desersi, insubordinasi, dan lain-lain juga tindak pidana 
Kedudukan Kejaksaan Republik Indonesia dalam Proses Penuntutan Peradilan Militer di Indonesia

umum, seperti perampokan, pemerkosaan, pembunuhan, atau pencurian, dan lain-lain maupun tindak pidana khusus, seperti penyalahgunaan psikotropika/shabu-shabu, narkotika, korupsi, dan lain-lain diadili di peradilan militer yang tidak ada kaitannya sama sekali dengan tugas-tugas/jabatan kemiliteran.

Meskipun bukan prajurit atau yang dipersamakan dengan prajurit melakukan tindak pidana, dan tindak pidana tersebut merugikan kepentingan militer serta dilakukan semata-mata dengan militer (perkara koneksitas) dapat diadili di peradilan militer. Apabila orang sipil (di luar PNS TNI) dapat diadili oleh peradilan militer, maka PNS TNI yang melakukan tindak pidana yang merugikan TNI seharusnya dapat diadili oleh peradilan militer.

Dalam penelitian dari Novalia (2018) yang berjudul "Analisis Yuridis Proses Penuntutan Perkara Koneksitas Dalam Tindak Pidana Korupsi Perspektif Hukum Positif” Masalah dalam tesis ini adalah analisis yuridis terkait dengan proses Penuntutan Kasus Perspektif dalam perspektif UU No. 20 tahun 2001 tentang Pemberantasan Tindak Pidana Korupsi dan Penentuan Tempat untuk Hakim Kasus konektivitas perspektif perspektif UU No. 20 tahun 2001 tentang Pemberantasan Korupsi. Berdasarkan hasil penelitian dan diskusi, setelah diberlakukannya UU Pemberantasan Korupsi dalam proses penuntutan kasus-kasus koneksi baik di tingkat pengadilan pertama (pertama) sampai Pengadilan Akhir masih mematuhi ketentuan sebagaimana dimaksud dalam Pasal No. 31 tahun 1997 tentang Pengadilan Militer (Pasal 198 - Pasal 203), UU No. 48 tahun 2009 tentang Kekuasaan Kehakiman (Pasal 16), UU No. 8 tahun 1981 tentang Hukum Acara Pidana (pasal 89-pasal 94) dan dalam menentukan tempat untuk mengadili kasus-kasus konektivitas berdasarkan analisis kasus menggunakan Pasal 89 ayat (1) dalam KUHAP.

Kemudian penelitian Slamet (2017) yang berjudul "Independensi Sistem Peradilan Militer di Indonesia (Studi Tentang Struktur Peradilan Militer)". Penelitian ini merupakan penelitian hukum yang menggunakan pendekatan yuridis normatif dipadukan dengan penelitian empiris. Penelitian ini mendapatkan hasil Peradilan militer merupakan salah satu sistem peradilan negara yang keberadaannya diatur berdasarkan undang-undang, antara lain dengan Undang Undang Nomor 7 tahun 1946 tentang peraturan tentang mengadakan pengadilan tentara disamping pengadilan biasa, dan Undang undang Nomor 8 tahun 1946 tentang peraturan hukum acara pidana guna pengadilan tentara. Filosofi terjadinya ketidakmandirian dalam sistem peradilan militer dikarenakan: 1) Faktor kepentingan militer (TNI) yang berkaitan dengan tugas pokok TNI mempertahankan kedaulatan negara, sehingga menggunakan peran komandan satuan (Ankum) maupun lembaga kepaperaan di dalam sistem penegakan hukum tersebut; 2) Adanya keberatan dari pihak TNI terhadap penempatan aparat sipil dalam system penegakan hukum bagi TNI yang pada awalnya ketua pengadilan negeri pada wilayah hukum pengadilan tentara karena jabatannya menjadi ketua pengadilan tentara, begitu juga panitera pengadilan negeri tersebut karena jabatannya menjadi panitera pengadilan tentara, kepala kejaksaan negeri yang karena jabatannya dapat ditetapkan sebagai jaksa tentara. Keberatan-keberatan tersebut didasari atas alasan bahwa system tersebut tidak menguntungkan bagi militer ataupun kesatuan.

Sejak tahun 2000-an gagasan pembentukan unsur pembantu Jaksa Agung di bidang Pidana Militer atau bisa disebut Jaksa Agung Muda Pidana Militer (Jampidmil) ini sudah sering 
dikumandangkan, namun seringkali menguap begitu saja tanpa ujung yang jelas. Di era kepemimpinan Jaksa Agung, Burhanuddin ini gagasan tersebut kembali terdengar.

Pada 22 Januari 2020 lalu, Persatuan Jaksa Indonesia (PJI) sebagai induk organisasi profesi para Jaksa menyelenggarakan Focus Group Discussion(FGF) ihwal masalah ini dengan mengundang pakar, pihak Oditurat Militer, serta NGO sebagai wakil masyarakat. Salah satu narasumber, Dr. Barita Simanjuntak, S.H., M.H., CFrA (Ketua Komisi Kejaksaan RI) mengatakan dukungan penuh terhadap pengembangan organisasi Kejaksaan melalui pembentukan Jaksa Agung Muda Pidana Militer ini. Menurutnya, pembentukan Jampidmil sejalan dengan prinsip jaksa adalah satu dan tidak terpisahkan dan untuk memperkuat eksistensi Kejaksaan sebagai pemegang asas dominus litis.

Pada realitanya hukum di Indonesia tidak sepi akan istilah equality before the law (Persamaan Di Depan Hukum). Baik itu dari para petani, buruh/pekerja, pedagang kaki lima, dan kelompok rentan. Maupun dari kelompok yang melakukan pelanggaran HAM, korupsi, dan penyalahgunaan kekuasaan. Walaupun kedua kelompok ini berbeda kepentingan. Tetapi dalam konteks hukum keduanya mempergunakan haknya sebagai subyek hukum untuk menuntut dan mempertahankan hak.

Istilah tersebut sangat sederhana, tetapi perlu ditelaah secara kritis. Karena penerapan Asas equality before the law, tergantung dari paradigma subyek hukum itu sendiri. Diturunkan menjadi teori hukum yang dianut oleh para ilmiator. Selain itu juga, yang paling penting adalah Aparatur hukum didalam penegakannya. Perspektif aparat penegak hukum dalam perannya dapat dilihat dari; Pertama; Terdakwa/Penasehat Hukum, Pandangan subyektif dari posisi yang subyektif. Kedua; Jaksa Penunutut
Umum, Pandangan subyektif dari posisi yang obyektif (mewakili kepentingan negara/masyarakat). Ketiga; Hakim, Pandangan obyektif dari posisi yang obyektif. Bagaimanapun aparatur mempunyai perspektif tersendiri didalam interprestasi terhadap Asas didalam perkara yang dikerjakan. Tetapi perlu kiranya, sebagai negara yang berdaulat, untuk memahami asas hukum dalam konteks tujuan negara. Disini dapat disebut sebagai asas equality befare the law ke Pancasilaan.

Pada masa jahiliyyah, tidak ada kesamaan di antara manusia. Tidak ada kesamaan antara tuan dan budak, antara pemimpin dengan rakyat biasa, antara si kaya dan si miskin, antara pria dan wanita. Dengan datangnya Islam, semua perbedaan atas dasar ras, warna, seks, bahasa, dan sebagainya dihapuskan. Syariat memberi tekanan yang besar pada prinsip equality before the law. Prinsip kesamaan tidak hanya terkandung dalam teori dan filosofi hukum Islam, tetapi dilaksanakan secara praktis oleh Rasulullah SAW, dan para khalifah penerus beliau (Santoso, 2000).

Dalam pandangan hukum Islam, semua manusia memiliki derajat yang sama meskipun bangsa dan golongan mereka berbeda-beda. Mereka mempunyai hak yang sama, kewajiban yang sama, dan tanggung jawab yang sama. Mereka diibaratkan gigi sisir yang rata, antara satu gigi dengan gigi yang lain tidak lebih tinggi atau lebih pendek. Seluruh manusia juga diibaratkan anak dari satu orang tua, kesatuan asal keturunan manusia ini menuntut persamaan hak, kewajiban, dan tanggung jawab. Karena itu tidak ada keutamaan antar seorang warga Negara dengan warga Negara lainnya (Muclish, 2004).

Pendapat pertama bersumber dari Imam Abu Hanifah. Ia berpendapat bahwa apabila imam tertinggi melakukan tindak pidana hudud, seperti 
melakukan zina, minum khamar, dan qazaf, sang imam tersebut tidak dikenai hukuman hudud kecuali bila ia melakukan tindak pidana qisas (pembunuhan) dan mengambil harta orang lain. Maka dari itu, apabila dia membunuh atau merusak harta seorang, ia dikenai hukuman atas tindakannya tersebut (Audah, 2007).

Pendapat kedua bersumber dari Imam Malik, asy-Syaafii dan Ahmad bin Hanbal. Dalam kaitan ini, mereka tidak membeda-bedakan tindak pidana yang dilakukan oleh seorang Imam. Mereka berpendapat bahwa seorang imam bertanggung jawab atas seluruh tindak pidana, baik menyentuh hak Allah maupun hak perseorangan. Hal ini karena nas-nas bersifat umum dan tindak pidana diharamkan kepada seluruh orang, dimana imam termasuk didalamnya. Artinya, siapa yang melakukan tindak pidana, ia diberi hukuman sekalipun yang melakukan adalah imam.

Dalam pandangan hukum Islam, semua manusia memiliki derajat yang sama meskipun bangsa dan golongan mereka berbeda-beda. Mereka mempunyai hak yang sama, kewajiban yang sama, dan tanggung jawab yang sama. Mereka diibaratkan gigi sisir yang rata, antara satu gigi dengan gigi yang lain tidak lebih tinggi atau lebih pendek. Seluruh manusia juga diibaratkan anak dari satu orang tua, kesatuan asal keturunan manusia ini menuntut persamaan hak, kewajiban, dan tanggung jawab. Karena itu tidak ada keutamaan antar seorang warga Negara dengan warga Negara lainnya (Muclish, 2004). Dari pernyataan di atas sangat jelas bahwa hukum Islam mengenal dan mempelajari mengenai istilah equality before the law.

Era reformasi yang menuntut transparansi, kebebasan, demokratisasi dan persamaan hak, berimbas kepada penyelenggaraan peradilan. Prinsip equality before the law menghendaki tidak ada warga Negara yang mendapat prevelege apalagi dalam bidang peradilan. Oleh karena itu tuntutan bahwa militer yang melakukan tindak pidana umum diadili di peradilan umum terus bergaung dan puncaknya adalah dikeluarkannya TAP MPRI RI Nomor VI/2000 dan TAP MPR RI Nomor VIII/2000 Jo Undang-undang Nomor 34 Tahun 2004 tentang ATNI yang menegaskan bahwa anggota militer yang melakukan kejahatan umum di bawa ke pengadilan sipil. Sedangkan Undang-undang Nomor 31 tahun 1997 tentang peradilan Militer mengatakan tindak pidana yang dilakukan anggota militer baik tindak pidana umum sebagaimana diatur dalam KUHP dan perundangundangan pidana lainnya, juga tindak pidana militer sebagaimana terdapat dalam KUHPM semuanya diadili di peradilan militer.

Melihat semangat yang terkandung dalam TAP MPR RI dan Undang-undang Nomor 34 tahun 2004 tentang TNI, Dewan Perwakilan Rakyat mengajukan usul inisiatif perubahan Undangundang Nomor 31 tahun 1997 tentang Peradilan Militer dengan alasan supaya terjadi sinkronisasi dengan Undang-undang Nomor 4 tahun 2004 tentang Kekuasaan Kehakiman.

\section{Kesimpulan}

Dengan berlakunya Undang-Undang Kejaksaan Tahun 2004, kewenangan Jaksa Agung sebagai Penuntut Umum Tertinggi tetap melekat sebagaimana diatur dalam Pasal 18 ayat (1) Undang-Undang ini. Namun dalam prakteknya khusus dalam peradilan militer, kewenangan penuntutan oleh Jaksa Agung hanya terbatas pada segi pengawasan, meskipun secara organisatoris Oditur Jenderal melalui Panglima bertanggung jawab kepada Jaksa Agung dalam melaksanakan tugas di bidang teknis penuntutan. 
Sistem pengadilan militer Indonesia sangat ringan menghukum tentara-tentara yang bersalah. Bahkan perlakuan terhadap masing-masing anggota militer yang tengah diproses hukum di pengadilan militer kerap tidak sama. Misalnya, pelaku yang berpangkat, kapten, mayor, hingga jenderal proses hukumnya berbeda dengan prajurit yang berpangkat letnan ke bawah. Hal seperti ini sangat mencederai asas equality before the law di negara hukum modern seperti Indonesia.

Untuk menciptakan relasi fungsional antara Jaksa dan Oditur Militer, maka perlu dilakukan penataan ulang kelembagaan di lingkungan Kejaksaan. Jaksa Agung selaku penuntut umum tertinggi sudah barang tentu harus memiliki unsur pembantu pimpinan yang fokus membantu tugastugasnya di bidang pidana militer "kejaksaan adalah satu dan tidak terpisahkan" (een en ondeelbaar). Artinya, penuntutan harus ada di satu lembaga, yakni Kejaksaan agar terpeliharanya kesatuan kebijakan di bidang penuntutan sehingga dapat menampilkan ciri khas yang menyatu dalam tata pikir, tata laku, dan tata kerjanya. Untuk itu disarankan agar proses penuntutan dilakukan dalam satu atap baik sipil maupun militer.

\section{Daftar Pustaka}

Abdul Qadir Audah, 2007, al-Tasyiri al-Jina'I AlIslami Muqaranam bil al-Qanun al-Wadh'I, (terj.Ali Yafie), Ensiklopedi Hukum Pidana Islam, jilid I, Bogor: PT Kharisma ilmu

Ahmad Wardi Muclish, 2004, Pengantar dan Azas Hukum Pidana Islam (Fiqh Jinayat), Jakarta: Sinar Grafika

Amiroedin Sjarif, 2006, Hukum disiplin militer di Indonesia, Jakarta: Rineka Cipta, Jakarta

Andi Hamzah dan RM Surachman, 2014. Pre-Trial Justice and discretionary Justice dalam KUHAP Berbagai Negara" Sinar Grafika, Jakarta

Charlieana Sari, "Latar Belakang Konstitusi Republik Indonesia Serikat", https://guruppkn.com/konstitusi-republik- indonesia-serikat, 18 Maret 2017, dikunjungi pada 2 Oktober 2019.

Din Nurdin, "Sejarah Peradilan Militer di Indonesia",

https://wonkdermayu.wordpress.com/artikel/ sejarah-peradilan-militer-di-indonesia/, dikunjungi pada 2 Oktober 2019.

Jhomson Siahaan, Hakim Pengadilan Militer I-01 Banda Aceh, 10 Juli 2017

Marwan Effendy, 2005, Kejaksaan RI: (Posisi dan Fungsinya dari Perspektif Hukum), PT Gramedia Pustaka Utama

Novalia Pertiwi, 2018, Analisis Yuridis Proses Penuntutan Perkara Koneksitas Dalam Tindak Pidana Korupsi Perspektif Hukum Positif, Tesis, Universitas Islam Malang.

Pengadilan Militer Utama, "Sejarah Peradilan Militer di Indonesia", https://www.dilmiltama.go.id/home/index.ph p/tentang-pengadilan/profile-

pengadilan/sejarah-pengadilan-militer.html, 12 Juni 2013, dikunjungi pada 2 Oktober 2019.

Pasal 64 Undang Undang Nomor 34 Tahun 2004 tentang Tentara Nasional Indonesia

Ray Pratama, "Proses Penuntutan di Pengadilan Militer",

https://raypratama.blogspot.com/2012/02/pro ses-penuntutan-di-pengadilan-militer.html, 12 Februari 2012, dikunjungi pada 2 Oktober 2019.

Slamet. Sarwo Edy, 2017, Independensi Sistem Peradilan Militer Di Indonesia (Studi Tentang Struktur Peradilan Militer), Disertasi, Universitas Gadjah Mada

S.R. Sianturi, 2006, Azas-Azas Hukum Pidana Di Indonesia dan Penerapannya, Jakarta : Alumni AHM-PTHM

Sugiri, dkk., 1976, 30 Tahun Perkembangan Peradilan Militer Di Indonesia, Babinkum TNI, Cet., Pertama

Topo Santoso, 2000, Membumikan Hukum Pidana Islam, Bandung: Asy Syaamil. 